\title{
Development of pigment-dispersing hormone-immunoreactive neurons in the American lobster: homology to the insect circadian pacemaker system?
}

\author{
Steffen Harzsch • Heinrich Dircksen • Barbara S. Beltz
}

Received: 25 July 2008 / Accepted: 22 October 2008 / Published online: 26 November 2008

(C) The Author(s) 2008. This article is published with open access at Springerlink.com

\begin{abstract}
We have examined the development of pigmentdispersing hormone (PDH)-immunoreactive neurons in embryos of the American lobster Homarus americanus Milne Edwards, 1837 (Decapoda, Reptantia, Homarida) by using an antiserum against $\beta-\mathrm{PDH}$. This peptide is detectable in the terminal medulla of the eyestalks and the protocerebrum where PDH immunoreactivity is present as early as $20 \%$ of embryonic development. During ontogenesis, an elaborate system of PDH-immunoreactive neurons and fibres develops in the eyestalks and the protocerebrum, whereas less labelling is present in the deuto- and tritocerebrum and the ventral nerve cord. The sinus gland is innervated by PDH neurites at hatching. This pattern of PDH immunoreactivity has been compared with that found in various insect species. Neurons immunoreactive to pigment-dispersing factor in the medulla have been shown
\end{abstract}

This study was supported by Deutsche Forschungsgemeinschaft (DFG) grant Ha 2540 and National Science Foundation grant IBN 0344448. S.H. was a Heisenberg Fellow of the DFG during the experimental part of this study. Bill Hansson and the Max Planck Society provided support during the final period of work reported in this paper.

\section{S. Harzsch $(\triangle)$}

Department of Evolutionary Neuroethology,

Max Planck Institute for Chemical Ecology,

Beutenberg Campus, Hans-Knöll-Strasse 8,

07745 Jena, Germany

e-mail: sharzsch@ice.mpg.de

URL: www.ice.mpg.de/han/home/home_en.htm

H. Dircksen

Department of Zoology, Stockholm University,

Stockholm, Sweden

B. S. Beltz

Department of Biological Sciences, Wellesley College,

Wellesley, Mass., USA to be a central component of the system that generates the circadian rhythm in insects. Our results indicate that, in view of the position of the neuronal somata and projection patterns of their neurites, the immunolabelled medulla neurons in insects have homologous counterparts in the crustacean eyestalk. Since locomotory and other activities in crustaceans follow distinct circadian rhythms comparable with those observed in insects, we suggest that PDHimmunoreactive medulla neurons in crustaceans are involved in the generation of these rhythms.

Keywords Peptide · Circadian clock · Evolution ·

Arthropoda $\cdot$ Malacostraca .

American lobster, Homarus americanus (Crustacea)

\section{Introduction}

Pigment-dispersing hormones (PDHs) are a family of octadecapeptides that, in crustaceans, mediate the dispersion of mainly black pigment granules within integumental chromatophores and the light adaptional movements of screening pigments in the ommatidia (for reviews, see Rao and Riehm 1989, 1993). In order to localise the sources of PDH and neuronal pathways utilising this peptide, an antiserum raised against synthetic $\beta$-PDH (Dircksen et al. 1987), which is the most common crustacean PDH (Rao et al. 1985), has been used to reconstruct the architecture of PDH-immunoreactive (PDHir) neurons in the adult crustacean nervous system, viz. in crabs and crayfish (Dircksen et al. 1987; Mangerich et al. 1987; Mangerich and Keller 1988; Nussbaum and Dircksen 1995; Hsu et al. 2008).

Pigment-dispersing factor-like-immunoreactivity (PDFli) has also been mapped in a variety of adult insects (Homberg et al. 1991a, b; Nässel et al. 1991, 1993; 
Helfrich-Förster and Homberg 1993; Würden and Homberg 1995; Petri et al. 1995; Reischig and Stengel 1996, 2002, 2003; Persson et al. 2001; Sehadová et al. 2003; for a review, see Homberg 1994). The receptors of the pigmentdispersing factor have been identified in insects (Hyun et al. 2005; Lear et al. 2005; Mertens et al. 2005). However, whereas the development of the PDFli system has been studied in several insect species such as Locusta migratoria (Dircksen 1994), Schistocerca gregaria (Homberg and Prakash 1996), Drosophila melanogaster (Helfrich-Förster 1997), and Musca domestica (Pyza et al. 2003), only one study on peptidergic neurones in embryos of the green shore crab, Carcinus maenas, has also included developmental aspects of PDHir neurons and the expression of the PDHmRNA throughout embryogenesis (Chung and Webster 2004). In both the crustacean and the insect nervous systems, the majority of PDFir/PDHir neurons and their neurites are localised in the eyestalks and the medial protocerebrum. Based on this observation, Homberg et al. (1991b) and Nässel et al. (1993) have suggested that a subset of the identified PDFli neurons in insects fulfils several morphological criteria of circadian pacemaker neurons. Furthermore, changes in the arborisation pattern of PDFli neurons associated with the medulla in mutants of the fruitfly $D$. melanogaster with altered circadian rhythmicity have indicated an involvement of PDFli neurons in the generation or modulation of the circadian rhythm (Helfrich-Förster and Homberg 1993). This claim has subsequently been substantiated by behavioural experiments combined with lesions in the optic ganglia of the cockroach (Stengl and Homberg 1994), by the finding that the protein of the period and timeless clock gene is colocalised with PDF in neurons in the medulla of $D$. melanogaster (Helfrich-Förster 1995; Hunter-Ensoe et al. 1996; Kaneko et al. 1997), pharmacological interference with synthetic PDH (Petri and Stengl 1997), the isolation of the PDF gene in D. melanogaster and an expression analysis in arrhythmic mutants (Park and Hall 1998), transplantation experiments (Reischig and Stengl 2003), mis-expression and mutation studies of the PDF gene (Renn et al. 1999; Helfrich-Förster et al. 2000) and tissue culture experiments (Petri and Stengl 1999). PDF is also known to be involved in a variety of morphological circadian changes of the cellular and subcellular components of the insect visual system (Pyza and Meinertzhagen 1996, 1997, 1998; Chen et al. 1999; Pyza 2002). Substantial evidence now exists that, in insects, a subset of PDF-expressing neurons in the optic ganglia and the brain play important roles in generating or modulating the rhythm of the circadian clock and in transmitting this message to the medial part of the brain (for reviews, see Helfrich-Förster 1996; Meinertzhagen and Pyza 1996; Helfrich-Förster et al. 1998; Meinertzhagen and Pyza 1999; Giebultowicz et al. 2001; Pyza 2001;
Tomioka et al. 2001; Helfrich-Förster 2002, 2003; Saunders 2002; Homberg et al. 2003).

As is now well established, adult decapod crustaceans display distinct circadian and circatidal rhythms of locomotor activity (Naylor 1988; Aréchiga et al. 1993; Naylor 1996; Palmer 2001) and retinal sensitivity rhythms (Aréchiga and Rodríguez-Sosa 1998; Fanjul-Moles and Prieto-Sagredo 2003). Earlier studies had shown that the 24-h rhythmicity of red and black chromatophore dispersion during colour changes in juvenile crabs, C. maenas, is primarily mediated by substances extractable from eyestalk ganglia; these are probably released from the sinus gland, as has been clearly determined by sinus gland ablation experiments (Powell 1966). Experiments involving eyestalk ablations and eyestalk extract injections have further substantiated that this rhythmicity is mediated by the release of a hormonal factor from the eyestalk neuroendocrine system (for reviews, see Aréchiga et al. 1985, 1993; Huberman 1996; Naylor 1996; Fanjul-Moles and PrietoSagredo 2003). Recent work with eyestalk perfusion experiments in crayfish has shown a clear-cut influence of $\mathrm{PDH}$ on the generation and expression of the circadian rhythmicity of the electroretinogram. Furthermore, in-vivoinjected PDH induces pigment migration characteristic of light adaptation and shifts the rhythm of response to light in photoreceptors (Verde et al. 2007). Since the behavioural repertoire of decapod crustacean larvae from hatching onwards comprises endogenous circadian and circatidal rhythms of vertical migration and moulting (Fanjul-Moles et al. 1996; Zeng and Naylor 1996a, b, c, d, 1997; Abello et al. 1997; Zeng et al. 1997; Fanjul-Moles and PrietoSagredo 2003), we have addressed the question as to whether a network of PDHir is present as early as when the embryos hatch and is possibly involved in the generation of such a rhythmicity. We have used an antiserum against $\beta$ PDH (Dircksen et al. 1987) to examine the development of PDHir neurons in embryos and juveniles of the American lobster Homarus americanus Milne Edwards, 1837 (Decapoda, Reptantia, Homarida). Recently, the $\beta$-PDH of the lobster H. americanus has been found to be identical in amino acid sequence sequence to the Uca-PDH ( $\mathrm{Fu}$ et al. 2005; Ma et al. 2008), which served as the antigen for the production of this antiserum. The positions of the labelled neuronal somata and projection patterns of their neurites indicate that most, if not all, of the insect PDFli groups of neurons in the optic ganglia and protocerebrum have counterparts in the crustacean brain. This is especially true of the neurons associated with the accessory medulla that, in insects, are likely to be a part of the circadian pacemaker system. Based on these results, we propose that PDHir neurons are involved in the generation or modulation of circadian or circatidal rhythms in decapod crustaceans, as in insects. 


\section{Materials and methods}

Ovigerous female lobsters Homarus americanus Milne Edwards, 1873 (Malacostraca, Pleocyemata, Homarida) were obtained from the lobster-rearing facility at the New England Aquarium (Boston, Mass.) and kept in recirculating artificial seawater $(30 \mathrm{ppt})$ at $18^{\circ} \mathrm{C}$ and a $12: 12 \mathrm{~h}$ lightdark regime (Harzsch et al. 1999a, b). Embryos were staged according to Helluy and Beltz (1991) on the basis of the length and width of the pigmented zone in the eye. The general layout and development of the nervous system in this species was recently reviewed by Harzsch (2002, 2003 ). In the present study, lobster embryos from $25 \%$ to $80 \%$ embryonic development (E25\% to E80\%) were used for immunohistochemical studies. Embryos were fixed overnight in $4 \%$ paraformaldehyde in $0.1 \mathrm{M}$ phosphate buffer ( $\mathrm{pH}$ 7.4) and 1\% 1-ethyl-3(3-dimethylaminopropyl) carbodiimide at $4^{\circ} \mathrm{C}$. Dissected whole-mounts of the embryos were washed in several changes of $0.1 \mathrm{M}$ phosphate-buffered saline (PBS) for $4 \mathrm{~h}$ and afterwards incubated in PBS containing 1\% normal goat serum (NGS) and $0.3 \%$ Triton $\mathrm{X}-100$ (PBS-TX) for $2 \mathrm{~h}$ at room temperature. Incubations in the polyclonal anti- $\beta \mathrm{PDH}$ antiserum $(1: 8,000$; for antibody production and characterisation, see Dircksen et al. 1987; Honda et al. 2006) were carried out overnight at $4^{\circ} \mathrm{C}$. The omission of primary antibody resulted in the complete absence of neuronal labelling. The specimens were then incubated in a biotinylated secondary antibody for $3 \mathrm{~h}$ (Vector) and subsequently for another $3 \mathrm{~h}$ in the peroxidase-conjugated avidin biotincomplex (Vectastain; Vector Laboratories). After being washed for $3 \mathrm{~h}$ in PBS, the tissues were reacted with $0.013 \%$ diaminobenzidine and a reagent containing hydrogen peroxide, cobalt chloride and nickel chloride (Amersham, RPN 20) for 7-9 min to reveal the peroxidase label. Finally, whole-mount preparations were dehydrated and mounted in Eukitt (Riedel-de Haen). Preparations were observed with a Nikon or Olympus microscope; labelled neurons and neuropils were drawn by using a camera-lucida attachment. The pattern of PDH immunoreactivity was reproducible between different specimens and was recorded in semi-schematic drawings based on the analysis of at least seven specimens for each developmental stage. The specimens were also photographed on 35 -mm black and whitefilm (25 ASA, Ilford); the negatives were scanned onto Kodak Photo $\mathrm{CD}$ and processed in Adobe Photoshop. Alternatively, after incubation in the primary antiserum, the embryos were incubated in a secondary anti-rabbit antibody conjugated to Alexa 488 (Molecular Probes) for $3 \mathrm{~h}$. The specimens were then washed in PBS, mounted in Gel mount (Sigma) and viewed with a Leica confocal laserscanning microscope. All confocal images presented here are based on stacks of between 5 and 20 optical sections (single images are averages of four laser sweeps) of a $\mathrm{z}$ series taken at $1-\mu \mathrm{m}$ intervals. Red-green three-dimensional (3D) images were generated from these stacks with the software provided with the Leica microscope.

\section{Results}

PDH immunoreactivity in the developing eyestalks

The eyestalks contain a pair of PDHir neurons (group A) and another single cell (B) associated with the medulla terminalis, even in the earliest embryonic stage examined (E25\%; Fig. 1). The neurites of these cells branch within the medulla terminalis and send their axons towards the protocerebrum via the protocerebral tract (Figs. 1, 2a,b, $3 \mathrm{c}, \mathrm{d}, 4 \mathrm{a}, 5)$. From the earliest stages onwards there also is a group of PDHir somata (group C) with neurites projecting towards the developing medulla externa (Figs. 1, 2). These cells are also the source of an immunopositive fibre bundle that runs towards the medulla terminalis and then joins the descending fibres of the group A cells. The system of fibre branches in the medulla externa becomes denser and more complex during successive development of the lobster embryos (Figs. 1, 2, 3, 4, 5, 6). This process is paralleled by an increase in numbers of immunoreactive somata within group $\mathrm{C}$ and, beginning at E35\% (Figs. 1, 3), the emergence of the sister clusters C' and C" next to cluster C. From E25\% to E80\%, the number of immunolabelled somata in cluster $\mathrm{C}$ and its sisters increases from 2 to about 22. In some specimens, the sister clusters appear well separated from cluster C (Figs. 4, 6), whereas in others, they merge with cluster $\mathrm{C}$. The neurites of these new sister clusters C' and C" form distinct bundles that meet the fibres of the existing cluster $\mathrm{C}$ neurons. The densely immunolabelled structures consisting of elaborately fasciculating axons and superimposed neuropilar fibre networks make it impossible to follow the course of single axons within a distinct branching point proximal to the medulla (arrows in Figs. 4b, 6b,c). However, within this branching point, some of the neurites from clusters C, C'and C" probably course towards the medulla externa, whereas others follow the thick fibre bundle towards the medulla terminalis and exit the eyestalk to target the brain. From this branching point, fibres also invade a small longitudinal neuropil (the medulla satellite neuropil proximal to the medulla) that extends anteriorly (Figs. 1, 2b, 4a, 6a). Fine immunoreactive fibres innervating the most proximal layer of the lamina ganglionaris are present by E45\% (Fig. 4). The 3D laser-scan images of the $60 \%$ lobster embryos reveal that the sinus gland is a spherical, densely PDHir structure close to, but clearly distinct from, the medulla externa (Figs. 1, 4, 6). Its innervation could not be traced 


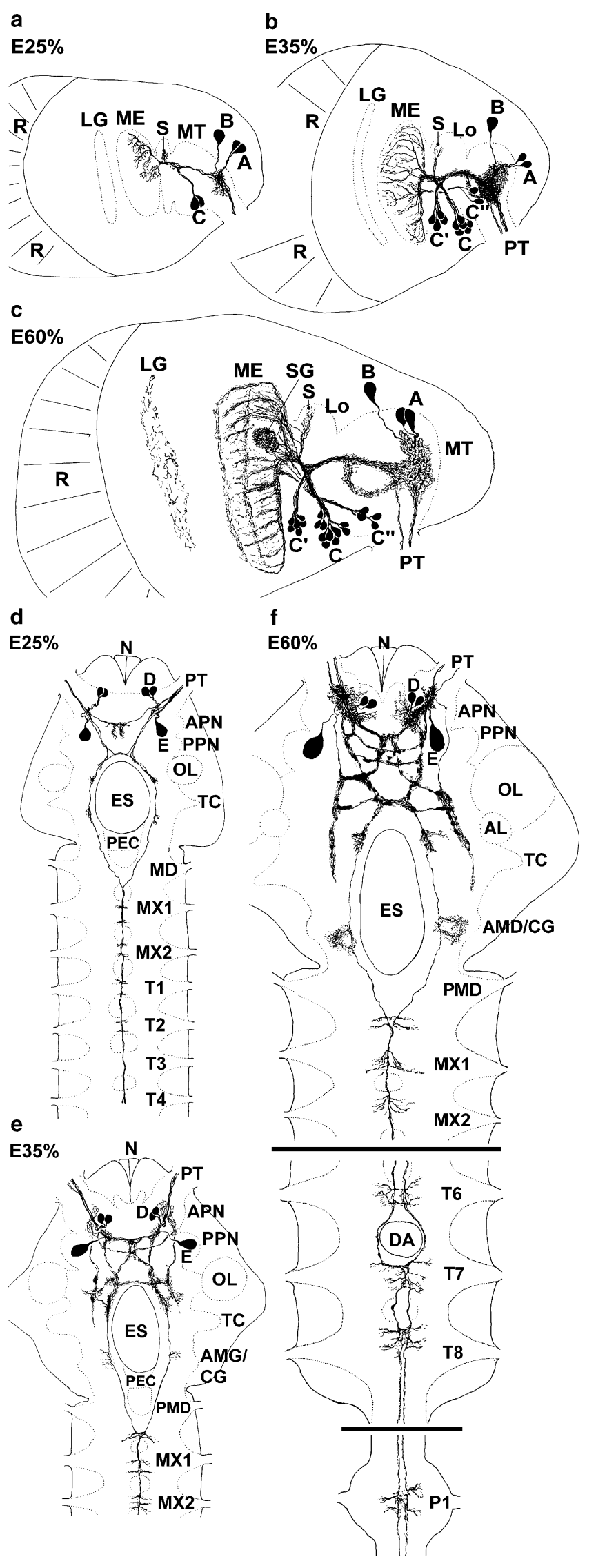

Fig. 1 Representations summarising the PDHir structures in embryonic lobster eyestalks (a-c) and median brains and ventral nerve cords (d-f) from $25 \%$ to $60 \%$ of embryonic development (E25\%-E60\%). Groups of neuronal somata are denoted by letters $A-E$ ( $A L$ accessory lobe, $A M D / C G$ anterior part of the mandibular neuromere, which is termed commissural ganglion in adult crustaceans, $A P N$ anterior protocerebral neuropil, $D A$ descending artery, $E S$ oesophageal foramen, $L G$ lamina ganglionaris, $L o$ lobula, $M E$ medulla externa, $M T$ medulla terminalis, $M X 1$ neuromeres of maxilla 1, $M X 2$ neuromeres of maxilla 2, $N$ nauplius eye, $O L$ olfactory lobe, $P 1$ pleon neuromere 1 , $P E C$ postoesophageal commissure, $P M D$ posterior part of the mandibular neuromere, $P P N$ posterior protocerebral neuropil, $P T$ protocerebral tract, $R$ retina, $S$ medulla satellite neuropil, $S G$ sinus gland, $T 1-8$ thoracic neuromeres $1-8, T C$ tritocerebrum)

unambiguously but PDHir fibres from soma groups C probably terminate in the sinus gland. Furthermore, a loose network of fibres, which is arranged at a level clearly ventral to those descibed so far, is in contact with the sinus gland but their origin could not be traced (Figs. 4, 6).

PDH immunoreactivity in the brain and ventral nerve cord

In $\mathrm{E} 25 \%$ and $\mathrm{E} 30 \%$ embryos, a fibre bundle composed of the neurites of cells A, B and C in the eyestalk enters the brain via the protocerebral tract and gives off branches that extend into the anterior protocerebrum where they form a small immunolabelled plexus (Figs. 1, 2). Later on in development, the axons of cell groups $\mathrm{C}^{\prime}$ and $\mathrm{C}$ " join this bundle. Some of the neurites within this tract cross the midline and enter the contralateral eyestalk via the protocerebral tract. Another portion of these fibres proceeds posteriorly and approaches the oesophageal foramen (Figs. 1, 2a,c, 3d,e). From the earliest embryonic stage onwards, two pairs of PDHir neurons (group D) and another large labelled cell (E) could be traced, all of which send their neurites into the protocerebral plexus (Figs. 1, 2c, $3 a, 5)$. The pattern of immunolabelled fibres in the protocerebrum becomes more and more complex throughout development. However, the components of the central complex (protocerebral bridge, central body, lateral lobes) are devoid of any labelling, as are the olfactory and accessory lobes. Whereas the axonal projection pattern of the protocerebral group D cells could not be determined, the axons of the large cells E most probably join the tract of axons that run from the eyestalks posteriorly towards the oesophagus (Fig. 1). Some of the axons in this tract cross over to the contralateral side in front of the oesophagus. The fibres then course around the oesophagus towards the ventral nerve cord (VNC). Side-branches of these neurites give rise to a small immunolabelled plexus at the anterior part of the mandibular neuromere, which is part of the socalled commissural ganglion in adult crustaceans [see Harzsch (2003) for a discussion of this nomenclature; Figs. 1, 3d,e]. The bilateral axonal tracts from the brain in all embryos examined enter the VNC via the circum- 
Fig. 2 Pigment-dispersing hormone (PDH)-immunoreactive (PDHir) structures at $30 \%$ of embryonic development. a Overview over the developing eyestalks and the brain; blackwhite inverted image, projection of a z-stack of confocal laserscan images. b, b' Left and right eyestalk, respectively. c Median brain of the same specimen as in a) colour-coded three-dimensional (3D) images (use redgreen glasses to view). Note the contralateral fibre link (open arrows in c) in the median brain. The sinus gland is not in focus in $\mathbf{b}, \mathbf{b}^{\prime}(C, D$ groups of neuronal somata, $A M D / C G$ anterior part of the mandibular neuromere, which is termed commissural ganglion in adult crustaceans, $M E$ medulla externa, $M T$ medulla terminalis, $P T$ protocerebral tract, $S$ medulla satellite neuropil). Bar $50 \mu \mathrm{m}$

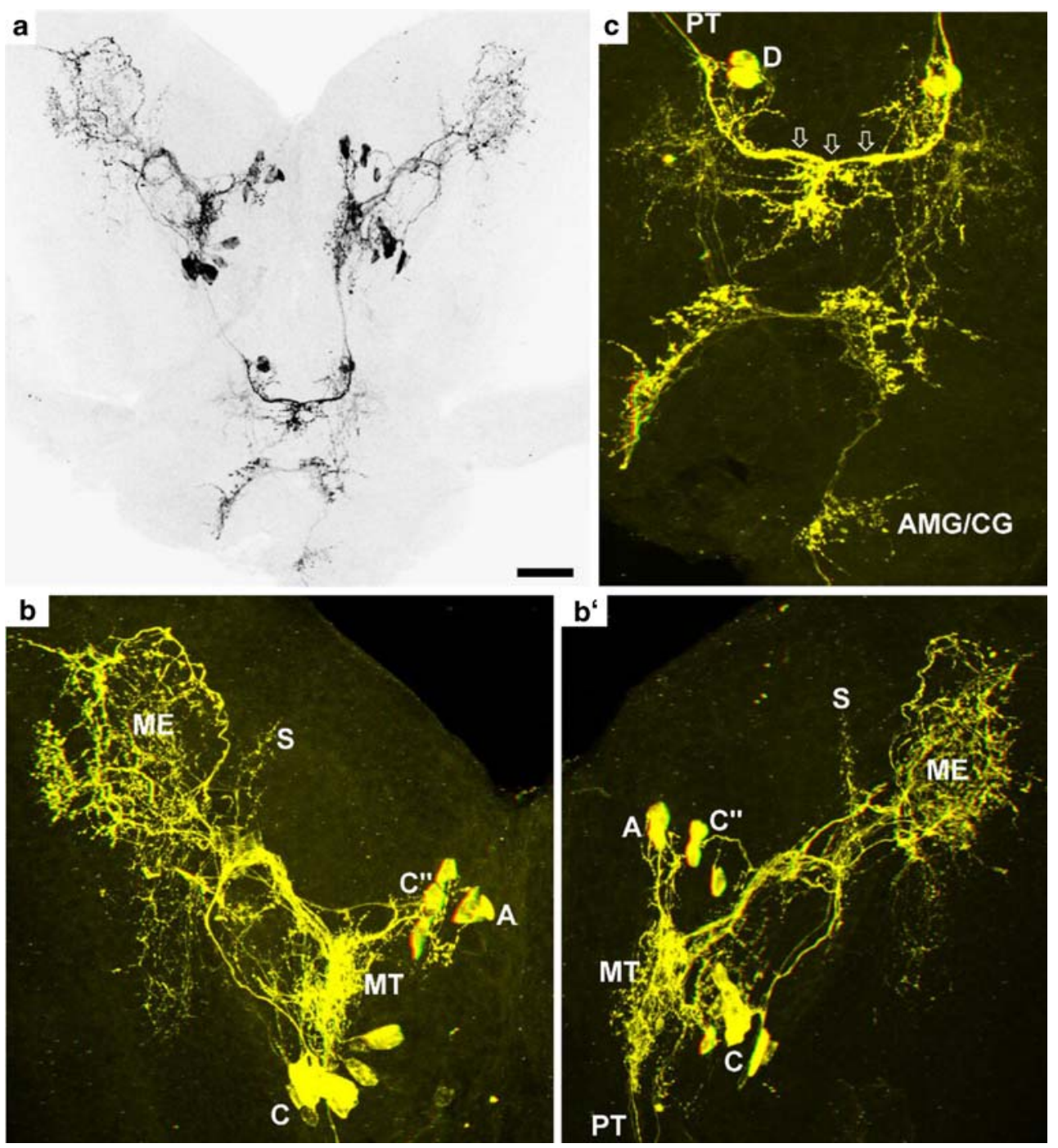

oesophageal connectives and join each other at the level of the posterior part of the mandibular neuromere (Figs. 1, 3f). From here, they proceed posteriorly to split up again into two separate tracts at the level of the third thoracic neuromere. These tracts, which could be traced caudally down through all pleon neuromeres (data not shown) give off tiny side-branches in each neuromere of the VNC (Fig. 3f).

\section{Discussion}

Comparison with adult crustaceans

The pattern of PDHir elements has been studied in the adult nervous systems of the shore crab C. maenas, the crayfish Orconectes limosus, and the woodlouse Oniscus asellus (Dircksen et al. 1987; Mangerich et al. 1987; Mangerich and Keller 1988; Nussbaum and Dircksen 1995). Many of the immunolabelled structures described in these reports can be found in the developing lobster nervous system at the earliest embryonic stages examined in the present study. Exceptions are the PDHir cells associated with the lamina ganglionaris in adult shore crabs and crayfish (Mangerich et al. 1987; Hsu et al. 2008), which are not present in lobster embryos but may develop postembryonically. Mangerich and coauthors (1987) have described two clusters of PDHir neurons comprising a total of 30-35 somata that correspond to cell groups $\mathrm{C}, \mathrm{C}$ ' and $\mathrm{C}$ " in the present report, although the number of cells within these clusters is smaller in the embryos that we have examined (about 22). However, evidence from studies with proliferation markers (Harzsch et al. 1999a, b; Harzsch 2002, 2003) indicates that neurogenesis is still under way in the stages of lobster embryos analysed in our study; therefore, additional PDH neurons may be generated in later stages. The pattern of the PDH immunoreactivity in the present study closely resembles that in embryos of the shore crab C. maenas (Chung and Webster 2004) in that the lobster eyestalk group C cells most probably correspond to the crab cell groups 2,4 and 5 . 
Fig. 3 a-c PDHir structures at $35 \%$ of embryonic development; bright-field images of diaminobenzidine-reacted specimens. a Natural pigmentation of the nauplius eye $(N E)$ is visible. b Note the contralateral fibre link in the median brain (arrows). c Note the conspicous branching point of the $\mathrm{C}$ neuron fibres (arrow). d-f PDHir structures at $45 \%$ of embryonic development; black-white inverted images, projections of z-stacks of confocal laser-scans. d Low-power overview of the developing eyestalks and median brain. $\mathbf{e}$ Higher magnification of the median brain (arrows contralateral fibre link in the median brain). f Fibres in the ventral nerve cord.-Groups of neuronal somata are denoted by letters $A$ $C$ and $E(A M D / C G$ anterior part of the mandibular neuromere, which is termed commissural ganglion in adult crustaceans, $E S$ oesophageal foramen, $M E$ medulla externa, $M T$ medulla terminalis, $M X 1$ neuromeres of maxilla 1, $M X 2$ neuromeres of maxilla 2, $P M D$ posterior part of the mandibular neuromere, $P T$ protocerebral tract, $T 1-6$ thoracic neuromeres 1-6). Bar $50 \mu \mathrm{m}$

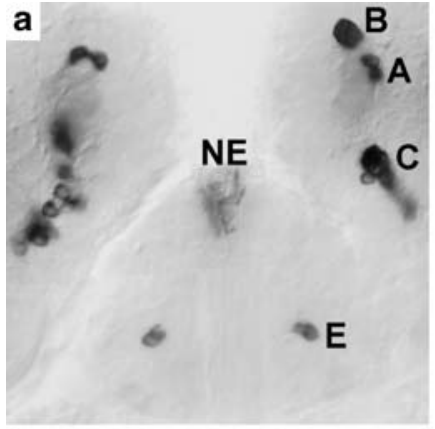

d
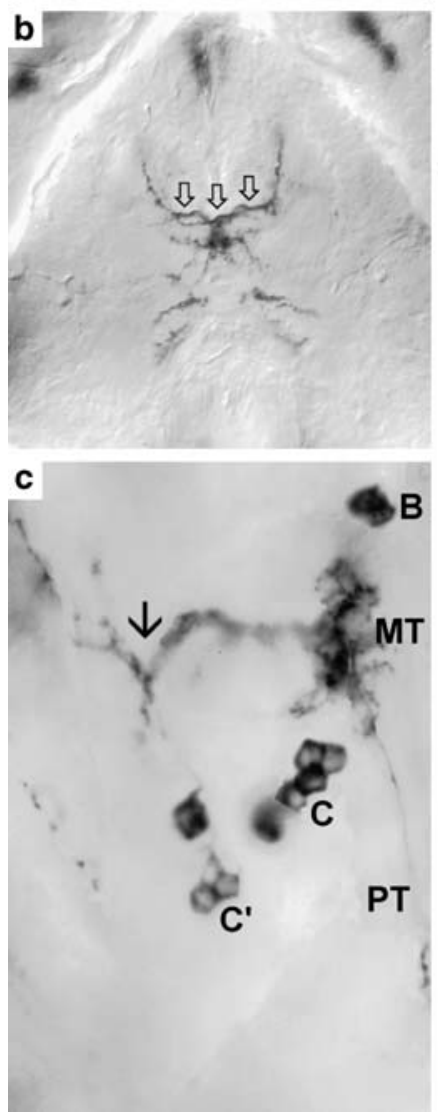

f

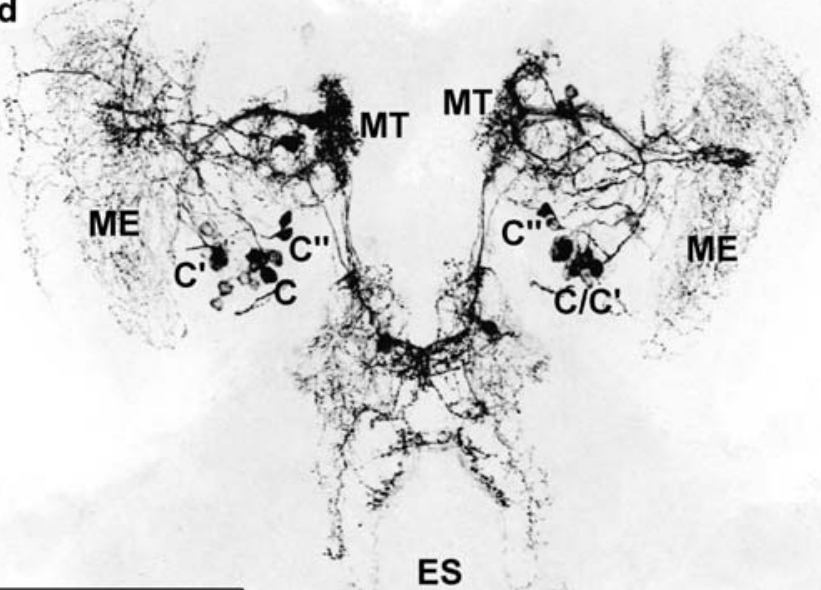

ES

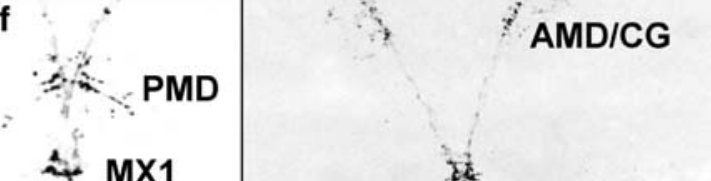

$M \times 1$

$M \times 2$

整 $\mathrm{T} 1$

然 T2

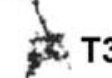

$T 3$

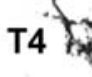

4

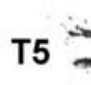

5

T6
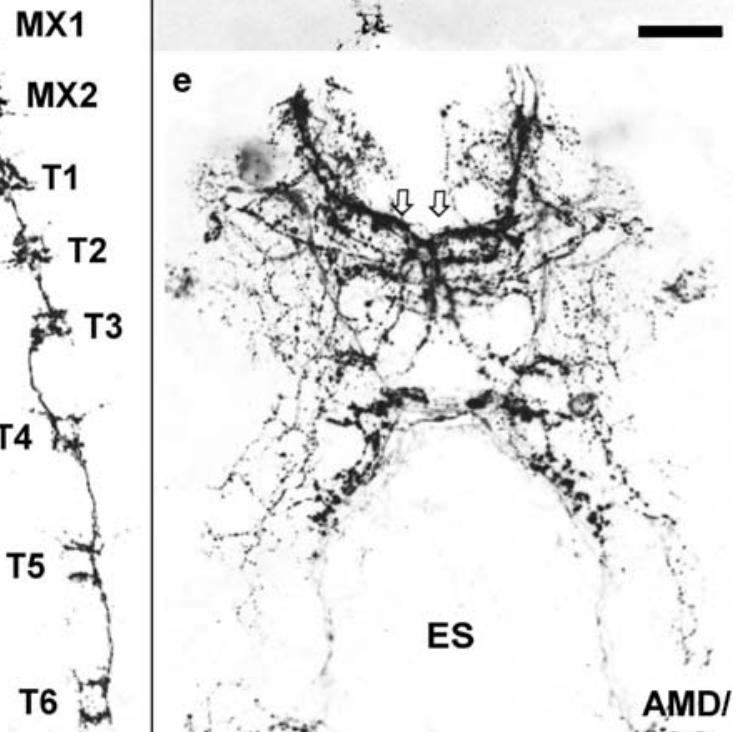

AMD/

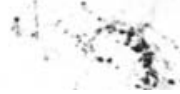

2.CG

Chung and Webster (2004) have also identified an early embryonic innervation of the lamina with PDHir structures, whereas in lobster embryos, instead the medulla seems to receive such an early input of PDHir fibres. In the woodlouse, a group of PDHir somata has been found (group 3 in Nussbaum and Dircksen 1995) that also shares the properties of group $\mathrm{C}$ cells and their sisters (as described in the present report) in that their fibres project towards the medulla externa and are the origin of a fibre bundle running towards the medulla terminalis. This latter bundle is also present in adult crayfish and crabs (Mangerich et al. 1987; Hsu et al. 2008). The neurons in groups A and B (present study) also have counterparts in the adult crustacean eyestalks where they are "located in the X-organ area" (Mangerich et al. 1987). In the adult woodlouse, a group of neurons associated with the medulla terminalis has been identified that send their axons towards the brain and further posteriorly into the VNC (group 2 in Nussbaum and Dircksen 1995). We therefore conclude that they correspond to group A cells in the present report. Furthermore, another group of PDHir somata associated with the adult woodlouse medulla terminalis is present (group 1, Nussbaum and Dircksen 1995), the neurites of which branch within the medulla terminalis and innervate the sinus gland. Although distinct immunolabelled fibres extend from the medulla terminalis towards the sinus gland in the lobster embryos examined in the present report, as in adult shore crabs and crayfish (Mangerich et al. 1987), the source of these fibres could not be clearly traced. Possible candidates are the group B cells or fibres ascending through the protocerebral tract from the brain or contralateral eyestalk. However, the more probable innervation of the sinus gland arises from 
Fig. 4 PDHir structures in the developing eyestalks at $45 \%$ of embryonic development (higher magnifications of the specimen shown in Fig. 3d); colour-coded 3D images (use red-green glasses to view). a, a' Left and right eyestalk, respectively (stars sinus gland). b, c Higher magnifications of a, a', respectively, showing the conspicous branching point of the $\mathrm{C}$ neuron fibres (arrows). Groups of neuronal somata are denoted by letters $A$ (circle) to $C$ (ME medulla externa, $M T$ medulla terminalis, $P T$ protocerebral tract, $S$ medulla satellite neuropil). Bar $50 \mu \mathrm{m}$
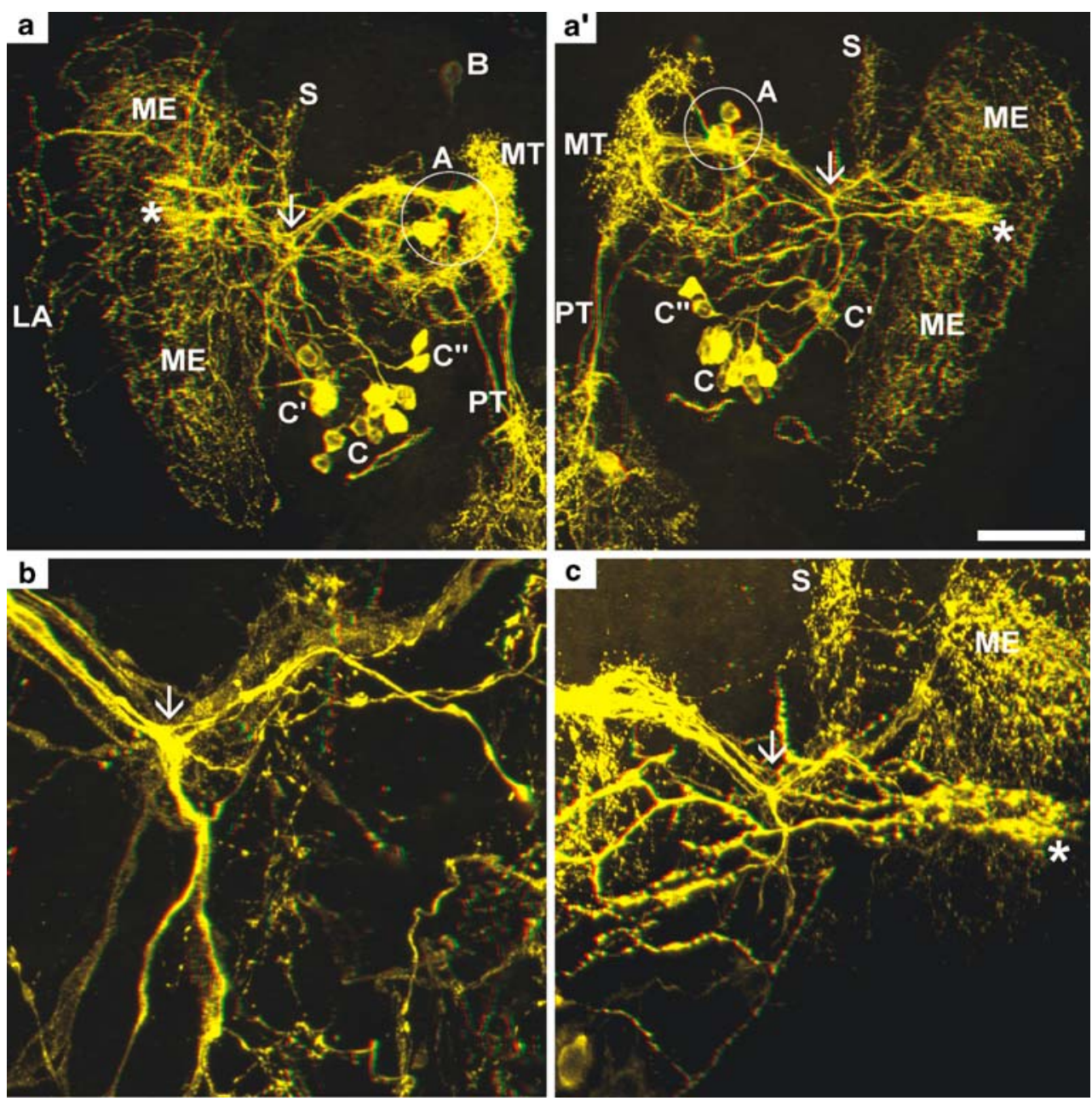

group C neurons in lobster embryos. This would closely match the situation in crabs, crayfish and woodlouse in which only three relatively large neurons with three fibres emerging from T-shaped branches in the large PDHir protocerebral tract usually occur, thus resembling those of the lobster group $\mathrm{C}$ embryonic neurons (especially the C' subgroup here; Mangerich et al. 1987; Nussbaum and Dircksen 1995; Hsu et al. 2008). Interestingly, Hsu et al. (2008) have found evidence, in adult crabs, for the existence of two different closely related $\beta$-PDHs (I and II) derived from two different precursors. The precursor of $\beta$-PDH-II appears to be preferentially expressed in three neurons innervating the sinus gland. Using tissue mass spectrometry, these authors have found $\beta$-PDH-II only in sinus glands together with $\beta$-PDH-I, an isoform apparently present in all other neurons. This finding resembles earlier results in crayfish in which three different $\beta$-PDH isoforms have been identified by nanoscale on-line liquid chromatography tandem mass spectrometry (Bulau et al. 2004). We cannot exclude the existence of further $\beta$-PDH isoforms in lobster embryos. However, these isoforms cannot be distinguished by the use of the $\beta$-PDH antiserum applied here, since it recognises epitopes similar or identical in all crustacean and insect $\beta$-PDH-like molecules (for more details, see Honda et al. 2006).

The median protocerebral PDHir somata, which are present in adult crabs and crayfish (Mangerich and Keller 1988; Hsu et al. 2008), are also present in the lobster embryos examined in the present report, as are the immunolabelled neuropils on the proto-, deuto- and tritocerebrum. However, the labelled somata in the adult deuto- and tritocerebrum are not observed in the lobster developmental stages and the same applies to the PDHir somata in the adult VNC (Mangerich and Keller 1988). In the $\mathrm{VNC}$ of all adult crustaceans hitherto analysed in this regard, a system of immunolabelled fibres that courses posteriorly from the brain with segmental side-branches in the VNC ganglia is present (Mangerich and Keller 1988; Chung and Webster 2004). The present study clearly shows that the VNC pathways are laid down as early as the embryonic stages. In adult crustaceans, PDHir structures are also present in the stomatogastric nervous system (Mortin and Marder 1991; Hsu et al. 2008) but we have not analysed this aspect in lobster embryos. 
Fig. 5 Overview of PDHir structures in the developing eyestalks and median brain at $80 \%$ of embryonic development. a Black-white inverted image from a projection of z-stacks of confocal laser-scans. b Colourcoded 3D image (use red-green glasses to view) of the median brain. Higher magnifications of this specimen including labels are provided in Fig. 6. Bar $50 \mu \mathrm{m}$
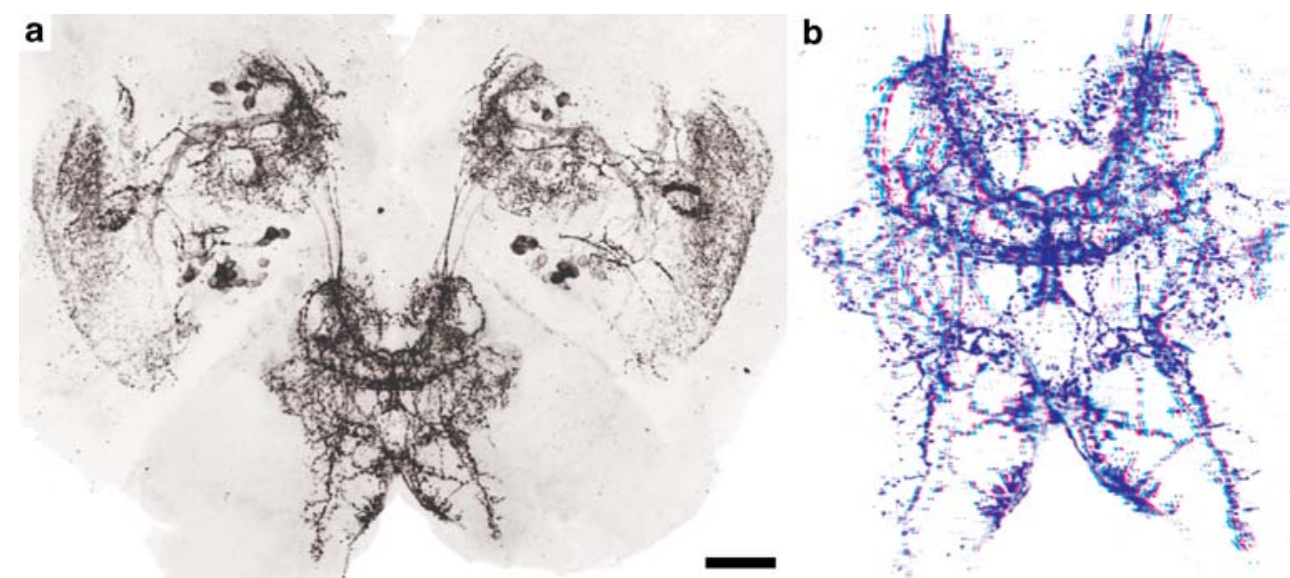

Comparison with insects

The neuronal expression of members of the PDH family of peptides has been mapped in a variety of insect species: the locust Schistocerca gregaria (Würden and Homberg 1995; Homberg and Prakash 1996) and seven other locust and cricket species (Homberg et al. 1991b), the cockroaches Leucophora maderae and Periplaneta americana (Homberg et al. 1991b; Nässel et al. 1991; Stengl and Homberg 1994; Petri et al. 1995; Reischig and Stengl 1996, 2002, 2003), the phasmid Extatosoma tiaratum (Homberg et al. 1991b), the sphinx moth Manduca sexta (Homberg et al. 1991a), several polyneopteran insects (Sehadová et al. 2003), the blowfly Phormia terraenovae (Nässel et al. 1991, 1993), the house fly M. domestica (Pyza et al. 2003) and the fruitfly $D$. melanogaster (Nässel et al. 1993; Helfrich-Förster and
Fig. 6 PDHir structures in the developing eyestalks at $80 \%$ of embryonic development (higher magnifications of the specimen shown in Fig. 5a); colour-coded 3D images (use red-green glasses to view). a, a' Left and right eyestalk, respectively (stars sinus gland). b, c Higher magnifications of a, a', respectively, showing the conspicous branching point of the $\mathrm{C}$ neuron fibres (arrows). Groups of neuronal somata are denoted by letters $A-C$ ( $M E$ medulla externa, $M T$ medulla terminalis, $P T$ protocerebral tract, $S$ medulla satellite neuropil). Bar $50 \mu \mathrm{m}$
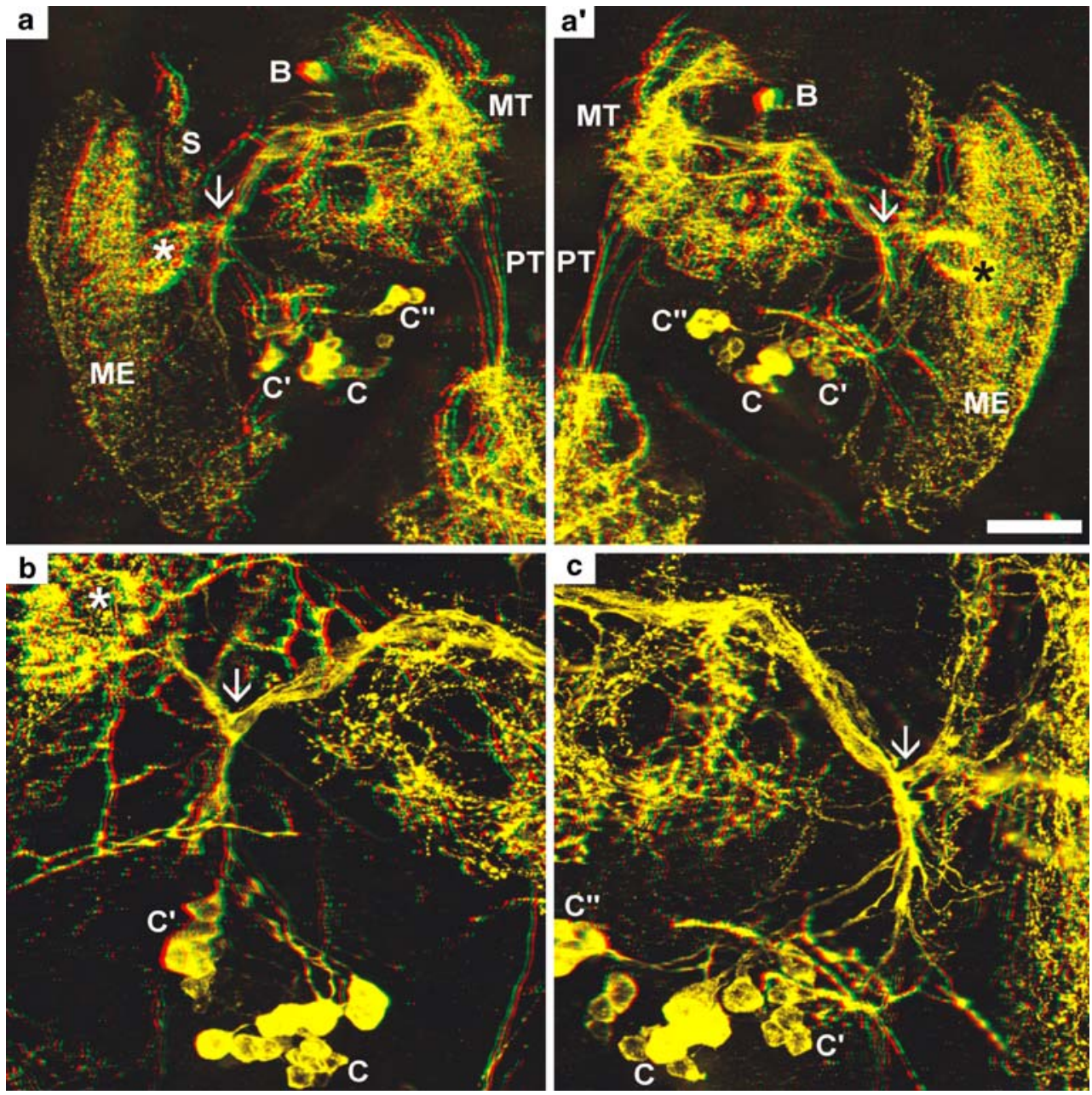
Homberg 1993; Helfrich-Förster 1995). For the first time, we embark here upon a comparison between insect and crustacean PDRir structures. We will begin in the distal part of the eyestalks and then proceed proximally towards the brain. We have aimed at applying the criteria for the homology of arthropod nervous structures as laid out by Kutsch and Breidbach (1994).

1. A cluster of PDHir cells similar to that associated with the crustacean lamina ganglionaris (Mangerich et al. 1987; Hsu et al. 2008) is also present in locusts, crickets and cockroaches (Homberg et al. 1991b; Nässel et al. 1991; Homberg and Prakash 1996). As in crustaceans, immunoreactive arborisations in the insect lamina are largely restricted to the inner, most proximal layer. The insect lamina neurons, however, are not evenly distributed below the lamina but are condensed into two clusters at the posterior dorsal and ventral edge of the lamina (cell groups PDFlad and PDFlav in Homberg et al. 1991b; Homberg and Prakash 1996). In flies, the lamina PDFli neurons are absent (Nässel et al. 1991, 1993; Helfrich-Förster and Homberg 1993).

2. In all insect species studied, two clusters of PDFli somata lie at the base of the medulla (Homberg et al. 1991b; Nässel et al. 1991, 1993; Helfrich-Förster 1995, 1997) in a position corresponding to the lobster group $\mathrm{C}$ neurons. The projection pattern of these two groups could not be unravelled unambiguously in all of the insects studied because of the superposition of numerous arborising processes in the regions critical for determination of origin (Homberg et al. 1991b; Nässel et al. 1991; Petri et al. 1995; Reischig and Stengl 1996). However, the most likely pattern is that the cells of one group of the insect medulla neurons send PDFli processes mainly into the medulla and the accessory medulla (Petri et al. 1995; Würden and Homberg 1995; Reischig and Stengl 1996) and give rise to a contralateral projection. These have been termed large pigmentdispersing factor-like immunoreactive medulla (PDFMe) neurons by Helfrich-Förster and Homberg (1993) and Helfrich-Förster (1995, 1997), large cell bodies by Nässel et al. (1991) and optic lobe 1 (OL1) neurons by Nässel et al. (1993). These cells, as in crustaceans, form several layers of immunopositive tangential processes in the medulla. We suggest that this cluster is homologous to the crustacean cell group $C$ and/or its sisters C' and C' because of the similarities in the position of the cell somata and projection patterns of the neurites. Specifically, these cells in Crustacea give rise to fibres that provide a link with the contralateral eyestalk, as is the case in insects. The accessory medulla and its associated neurons is a well-characterised neuropil in insects and is an integral part of the circadian pacemaker system in these groups (Homberg 1994; Petri et al. 1995; Würden and Homberg 1995; Reischig and Stengl 1996; Loesel and Homberg 2001). The paired accessory medullae in both optic lobes are coupled with each other by commissural fibres passing through the posterior optic tubercles and this anatomical link is supposed to play an important role in the synchronisation of the oscillations of these pacemakers (Reischig et al. 2004). A distinct crustacean equivalent to the insect accessory medulla has yet to be clearly identified, but the small longitudinal satellite neuropil at the base of the medulla described for the first time in the present report is a possible candidate. Immunohistochemical demonstration of additional neuropeptides in this satellite neuropil (compare Petri et al. 1995; Würden and Homberg 1995) will be necessary to substantiate this suggestion.

3. The second group of insect medulla neurons and the bundle of contralaterally projecting fibres of the first group give rise to extensive ramifications in several regions of the median protocerebrum: the lateral horn, which is a region adjacent to the mushroom body calyces and is most probably comparable with the lateral protocerebrum with the hemi-ellipsoid body in decapod crustaceans (Harzsch 2007); a median posterior neuropil close to the oesophageal foramen; a protocerebral neuropil posterior to the fan-shaped body of the central body complex. These cells have been termed small PDFMe neurons by Helfrich-Förster and Homberg (1993) and Helfrich-Förster (1995, 1997), small cell bodies (scb) by Nässel et al. (1991) and optic lobe 2 (OL2) neurons by Nässel et al. (1993). We suggest that they are homologous to the crustacean group C, C' and/or C" neurons because of the similarities in the position of the cell somata and projection patterns of the neurites.

4. Our hypothesis regarding the homology of the lobster $\mathrm{C}$ neurons is substantiated by a comparison with the emergence of the small and large PDFMe neurons in the fruitfly D. melanogaster (Helfrich-Förster 1997). In the brain of this animal, pigment-dispersing factor-like immunoreactive neurons appear in first-instar larvae 4$5 \mathrm{~h}$ after hatching. A cluster of four small PFFMe neurons is the first to appear, and this cluster persists throughout pupal development into adulthood. Their putative postsynaptic endings are associated with the accessory medulla. Four to six large PDFMe neurons appear halfway through pupal development in a position close to the small PDFMe neurons. Their arborisations extend into the accessory medulla and also innervate the medulla. They also give rise to immunolabelled fibres in the posterior optic tract to the 
contralateral optic lobe (Helfrich-Förster 1997). The similarities in developmental appearance and projection pattern suggest a correspondence of the pupal small and large PDFMe neurons of $D$. melanogaster with the embryonic C, C', and C" neurons of the lobster, but a more specific statement is not possible at this point. The differences are that, in the fly, a maximum of ten neurons is present, whereas in lobster, there are approximately twenty. Furthermore, the embryonic lobster cells do not display a clear-cut size difference as the fly cells do.

5. A further cluster of PDFli neurons is present in the medial part of the insect protocerebrum, close to the site where the fibres from the medulla cells terminate, i.e. the lateral horn adjacent to the calyces of the mushroom bodies. These neurons have been termed pigment-dispersing factor-like immunoreactive calyx (PDFca) neurons in the fruitfly (Helfrich-Förster 1995, 1997), posterior dorsal (PD) neurons in the blowfly (Nässel et al. 1993) and pars intercerebralis neurons in crickets and the sphinx moth (Homberg et al. 1991a, b). Immunoreactive fibres from these cells join the median bundle and project towards the oesophageal foramen and then proceed further posteriorly towards the VNC. We suggest that these cells are homologous to the crustacean neurons A and B for the following reasons: the medulla interna/terminalis complex ("lateral protocerebrum") in the crustacean eyestalks is a structure that phylogenetically is derived from the protocerebrum (Vilpoux et al. 2006). Therefore, the crustacean medulla terminalis, together with the hemi-llipsoid body, probably corresponds to the insect lateral horns (Harzsch 2007). The termination site of the axons of the insect medulla neuron in the lateral horn may hence correspond to the innervation of crustacean group $\mathrm{C}, \mathrm{C}$ ' and $\mathrm{C}$ " neurons in the medulla terminalis. This is the reason that the afore-mentioned PDFli cells close to the insect lateral horn might be homologous to the crustacean group $\mathrm{A}$ and $\mathrm{B}$ cells in the medulla terminalis. The insect protocerebral neurons and crustacean group A cells also share the same projection pattern in that their neurites proceed posteriorly towards the VNC.

Insect and crustacean circadian rhythms

Insects are known to display distinct circadian rhythms of motor activity and, in the last few years, the cellular and molecular mechanisms of the circadian clock have been elucidated (reviews Helfrich-Förster 1996; Meinertzhagen and Pyza 1996; Helfrich-Förster et al. 1998; Meinertzhagen and Pyza 1999; Giebultowicz et al. 2001; Pyza 2001; Tomioka et al. 2001; Helfrich-Förster 2002, 2003; Saunders
2002; Homberg et al. 2003). Homberg et al. (1991b) and Nässel et al. (1993) have suggested that the medulla PDFli neurons in insects fulfil several morphological criteria of circadian pacemaker neurons in that they are well suited to pick up visual stimuli and transfer this information to the medial part of the brain, and because they have an anatomical link for contralateral coupling.

From the results in the present study, we propose that the insect PDFli medulla neurons are homologous to the crustacean PDHir neurons of group C. Adult decapod crustaceans display distinct circadian and circatidal rhythms of locomotor activity (Naylor 1988; Aréchiga et al. 1993; Naylor 1996; Palmer 2001). What is more, crustacean larvae display endogenous circadian and circatidal rhythms of vertical migration (Fanjul-Moles et al. 1996; Zeng and Naylor 1996a, b, c, d, 1997) and retinal sensitivity rhythms (Fanjul-Moles and Prieto-Sagredo 2003) and larval moulting is also influenced by circatidal rhythmicity (Abello et al. 1997; Zeng et al. 1997). Since we have been able to show that, in late lobster embryos, an elaborate system of PDH medulla neurons is present, we propose that this system, as in insects, plays a functional role in the circadian/circatidal clock of crustacean larvae.

Evolutionary implications: "neurophylogeny" and arthropod relationships

The structure and development of the nervous system contribute important arguments to the revived debate on arthropod relationships, so that arthropod "neurophylogeny", i.e. the synthesis of neurobiology and phylogenetic analyses, is now a well-established and active discipline (for recent contributions, see Loesel 2004, 2005; Harzsch et al. 2005; Strausfeld 2005; Harzsch 2006; 2007; Harzsch and Hafner 2006; Strausfeld et al. 2006a, b; Heuer and Loesel 2008; Mayer and Harzsch 2008). Specifically, the considerable number of recent studies of the brain architecture in various non-model arthropods reflects the progress that we have made in analysing the cellular architecture of the arthropod brain in a depth that can provide detailed character sets with a strong impact on our understanding of arthropod phylogeny (e.g. Loesel et al. 2002; Schachtner et al. 2005; Strausfeld 2005; Fanenbruck and Harzsch 2005; Strausfeld et al. 2006a, b; Homberg 2008). All recent studies in this field have collectively indicated a closer phylogenetic affinity of insects with crustaceans (Tetraconata hypothesis) rather than with myriapods (Tracheate hypothesis; for reviews, see Harzsch 2006, 2007). The current study, which provides evidence for a close similarity of a certain identified neuronal system in Hexapoda and malacostracan Crustacea, might provide a basis for a new approach in this direction. In order to extract meaningful phylogenetic information, the 
next step should be to analyse PDH immunolocalisation in the brains of non-malacostracan crustaceans and myriapods as the potential outgroups to the Hexapoda and Malacostraca.

Acknowledgements The authors wish to thank J. Goldstein from the New England Aquarium (Boston) and M. Syslo from the Massachusetts State Lobster Hatchery at Martha's Vineyard for providing egg-bearing lobster females. T. Reischig is greatfully acknowledged for his comments on the manuscript and D. C. Sandeman and J. Benton for discussion.

Open Access This article is distributed under the terms of the Creative Commons Attribution Noncommercial License which permits any noncommercial use, distribution, and reproduction in any medium, provided the original author(s) and source are credited.

\section{References}

Abello P, Warman CG, Naylor E (1997) Circatidal moulting rhythm in the shore crab Carcinus maenas. J Mar Biol Assoc UK 77:277-280

Aréchiga H, Rodríguez-Sosa L (1998) Circadian clock function in isolated eyestalk tissue of crayfish. Proc R Soc Lond [Biol] 265:1819-1823

Aréchiga H, Flores J, García U (1985) Biosynthesis and release of the crustacean neurodepressing hormone. In: Lofts B, Holmes WN (eds) Current Trends in Comparative Endocrinology. Hong Kong University Press, Hong Kong, pp 787-791

Aréchiga H, Fernandez-Quiroz F, Fernandez de Miguel F, RodríguezSosa L (1993) The circadian system of crustacean. Chronobiol Int 10:1-19

Bulau P, Meisen I, Schmitz T, Keller R, Peter-Katalinić J (2004) Identification of neuropeptides from the sinus gland of the crayfish Orconectes limosus using nanoscale on-line liquid chromatography tandem mass spectrometry. Mol Cell Proteomics 3:558-564

Chen B, Meinertzhagen IA, Shaw SR (1999) Circadian rhythms in lightevoked responses of the fly's compound eye, and the effects of neuromodulators 5-HT and the peptide PDF. J Comp Physiol [A] 185:393-404

Chung JS, Webster SG (2004) Expression and release patterns of neuropeptides during embryonic development and hatching of the green shore crab, Carcinus maenas. Development 131:4751-4761

Dircksen H (1994) Pigment-dispersing hormone-immunoreactive neurons in the ventral nervous system of the locust, Locusta migratoria, during development. In: Elsner N, Breer H (eds) Göttingen Neurobiology Report 1994. Thieme, Stuttgart New York, p 684

Dircksen H, Zahnow CA, Gaus G, Keller R, Rao KR, Riehm JP (1987) The ultrastructure of nerve endings containing pigmentdispersing hormone (PDH) in crustacean sinus glands: identification by an antiserum against a synthetic PDH. Cell Tissue Res 250:377-387

Fanenbruck M, Harzsch S (2005) A brain atlas of Godzilliognomus frondosus Yager, 1989 (Remipedia, Godzilliidae) and comparison with the brain of Speleonectes tulumensis Yager, 1987 (Remipedia, Speleonectidae): implications for arthropod relationships. Arthropod Struct Dev 34:343-378

Fanjul-Moles ML, Prieta-Sagredo J (2003) The circadian system of crayfish: a developmental approach. Microsc Res Tech 60:291-301

Fanjul-Moles ML, Miranda-Anaya M, Prieto J (1996) Circadian locomotor activity rhythm during ontogeny in crayfish Procambarus clarkii L. Chronobiol Int 13:15-26
Fu Q, Goy MF, Li L (2005) Identification of neuropeptides from the decapod crustacean sinus glands using nanoscale liquid chromatography tandem mass spectrometry. Biochem Biophys Res Commun 337:765-778

Giebultowicz JM, Ivanchenko M, Vollintine T (2001) Organization of the insect circadian system: spatial and developmental expression of clock genes in peripheral tissues of Drosophila melanogaster. In: Denlinger DL, Giebultowicz JM, Saunders DS (eds) Insect timing: circadian rhythmicity to seasonality. Elsevier, London New York, pp 31-42

Harzsch S (2002) From stem cell to structure: neurogenesis in the CNS of decapod crustaceans. In: Wiese K (ed) The crustacean nervous system. Springer, Berlin Heidelberg New York, pp 417-432

Harzsch S (2003) Ontogeny of the ventral nerve cord in malacostracan crustaceans: a common plan for neuronal development in Crustacea, Hexapoda and other Arthropoda? Arthropod Struct Dev 32:17-37

Harzsch S (2006) Neurophylogeny: architecture of the nervous system and a fresh view on arthropod phyologeny. Comp Integr Biol 46:162-194

Harzsch S (2007) Architecture of the nervous system as a character for phylogenetic reconstructions: examples from the Arthropoda. Species Phylogeny Evol 1:33-57

Harzsch S, Hafner G (2006) Evolution of eye development in arthropods: phylogenetic implications. Arthropod Struct Dev 35:319-340

Harzsch S, Miller J, Benton J, Beltz B (1999a) From embryo to adult: persistent neurogenesis and apoptotic cell death shape the lobster deutocerebrum. J Neurosci 19:3472-3485

Harzsch S, Benton J, Dawirs RR, Beltz B (1999b) A new look at embryonic development of the visual system in decapod crustaceans: neuropil formation, neurogenesis and apoptotic cell death. J Neurobiol 39:294-306

Harzsch S, Müller CHG, Wolf H (2005) From variable to constant cell numbers: cellular characteristics of the arthropod nervous system argue against a sister-group relationship of Chelicerata and "Myriapoda" bur favour the Mandibulata concept. Dev Genes Evol 215:53-68

Helfrich-Förster C (1995) The period clock gene is expressed in central nervous system neurons which also produce a neuropeptide that reveals the projections of circadian pacemaker cells within the brain of Drosophila melanogaster. Proc Natl Acad Sci USA 92:612-616

Helfrich-Förster C (1996) Drosophila rhythms: from brain to behavior. Semin Cell Dev Biol 7:791-802

Helfrich-Förster C (1997) Development of pigment-dispersing hormone-immunoreactive neurons in the nervous system of Drosophila melanogaster. J Comp Neurol 380:335-354

Helfrich-Förster C (2002) The circadian system of Drosophila melanogaster and its light input pathways. Zoology 105:297-312

Helfrich-Förster C (2003) The neuroarchitecture of the circadian clock in the brain of Drosophila melanogaster. Micros Res Tech 62:94-102

Helfrich-Förster C, Homberg U (1993) Pigment-dispersing hormoneimmunoreactive neurons in the nervous system of wild-type Drosophila melanogaster and of several mutants with altered circadian rhythmicity. J Comp Neurol 337:177-190

Helfrich-Förster C, Stengl M, Homberg U (1998) Organization of the circadian system in insects. Chronobiol Int 15:567-594

Helfrich-Förster C, Täuber M, Park JH, Mühlig-Versen M, Schneuwly S, Hofbauer A (2000) Ectopic expression of the neuropeptide pigment-dispersing factor alters behavioral rhythms in Drosophila melanogaster. J Neurosci 20:3339-3353

Helluy SM, Beltz BS (1991) Embryonic development of the American lobster (Homarus americanus): quantitative staging and characterization of an embryonic molt cycle. Biol Bull 180:355-371 
Heuer CM, Loesel R (2008) Immunofluorescence analysis of the internal brain anatomy of Nereis diversicolor (Polychaeta, Annelida). Cell Tissue Res 331:713-724

Homberg U (1994) Distribution of neurotransmitters in the insect brain. Progress in Zoology, vol 40. Fischer, Stuttgart Jena New York

Homberg U (2008) Evolution of the central complex in the arthropod brain with respect to the visual system. Arthropod Struct Dev 37:347-362

Homberg U, Prakash N (1996) Development of pigment-dispersing hormone-like immunoreactivity in the brain of the locust Schistocerca gregaria: comparison with immunostaining for urotensin I and Mas-allatotropin. Cell Tissue Res 285:127-139

Homberg U, Davis NT, Hildebrand JG (1991a) Peptide-immunocytochemistry of neurosecretory cells in the brain and retrocerebral complex of the sphinx moth Manduca sexta. J Comp Neurol 303:35-52

Homberg U, Würden S, Dircksen H, Rao KR (1991b) Comparative anatomy of pigment-dispersing hormone-immunoreactive neurons in the brain of orthopteroid insects. Cell Tissue Res 266:343-357

Homberg U, Reischig T, Stengl M (2003) Neural organization of the circadian system of the cockroach Leucophaea maderae. Chronobiol Int 20:577-591

Honda T, Matsushima A, Sumida K, Chuman Y, Sakaguchi K, Onoue H, Meinertzhagen IA, Shimohigashi Y, Shimohigashi M (2006) Structural isoforms of the circadian neuropeptide PDF expressed in the optic lobes of the cricket Gryllus bimaculatus: immunocytochemical evidence from specific monoclonal antibodies. J Comp Neurol 499:404-421

Hsu YW, Stemmler EA, Messinger DI, Dickinson PS, Christie AE, Iglesia HO de la (2008) Cloning and differential expression of two beta-pigment-dispersing hormone (beta-PDH) isoforms in the crab Cancer productus: evidence for authentic beta-PDH as a local neurotransmitter and beta-PDH II as a humoral factor. J Comp Neurol 508:197-211

Huberman A (1996) Neurodepressing hormone (NDH): fact or fiction? Crustaceana 69:1-18

Hunter-Ensor M, Ousley A, Sehgal A (1996) Regulation of the Drosophila protein timeless suggests a mechanism for resetting the circadian clock by light. Cell 84:677-685

Hyun S, Lee Y, Hon ST, Bang S, Paik D, Kang J, Shin J, Lee J, Jeon K, Hwang S, Bae K, Hwang S, Bae E, Kim J (2005) Drosophila GRCR Han is a receptor for the circadian clock neuropeptide PDF. Neuron 48:267-278

Kaneko M, Helfrich-Förster C, Hall JC (1997) Spatial and temporal expression of the period and timeless genes in the developing nervous system of Drosophila: newly identified pacemaker candidates and novel features of clock gene product cycling. $\mathrm{J}$ Neurosci 17:6745-6760

Kutsch W, Breidbach O (1994) Homologous structures in the nervous system of Arthropoda. Adv Insect Physiol 24:1-113

Lear BC, Marrill E, Lin JM, Schroeder A, Zhang L, Allada R (2005) A G-protein-coupled receptor, groom-of-PDF, is required for PDF neuron action in circadian behavior. Neuron 48:221-227

Loesel R (2004) Comparative morphology of central neuropils in the brain of arthropods and its evolutionary and functional implications. Acta Biol Hung 55:39-51

Loesel R (2005) The arthropod brain: retracing six hundred million years of evolution. Arthropod Struct Dev 34:207-209

Loesel R, Homberg U (2001) Anatomy and physiology of neurons with processes in the accessory medulla of the cockroach Leucophaea maderae. J Comp Neurol 439:193-207

Loesel R, Nässel DR, Strausfeld NJ (2002) Common design in a unique midline neuropil in the brains of arthropods. Arthropod Struct Dev 31:77-91
Ma M, Chen R, Sousa GL, Bors EK, Kwiatkowski M, Goiney CC, Goy MF, Christie AE, Li L (2008) Mass spectral characterization of peptide transmitters/hormones in the nervous system and neuroendocrine organs of the American lobster Homarus americanus. Gen Comp Endocrinol 156:395-340

Mangerich S, Keller R (1988) Localization of pigment-dispersing hormone (PDH) immunoreactivity in the central nervous system of Carcinus maenas and Orconectes limosus (Crustacea), with reference to FMRFamide immunoreactivity in O. limosus. Cell Tissue Res 253:199-208

Mangerich S, Keller R, Dircksen H, Rao KR, Riehm JP (1987) Immunocytochemical localization of pigment-dispersing hormone (PDH) and its coexistence with FMRFamide-immunoreactive material in the eyestalks of the decapod crustaceans Carcinus maenas and Orconectes limosus. Cell Tissue Res 250:365-375

Mayer G, Harzsch S (2008) Distribution of 5-HT-like immunoreactivity in the trunk of Metaperipatus blainvillei (Onychophora, Peripatopsidae): implications for nervous system evolution in Arthropoda. J Comp Neurol 507:1196-1208

Meinertzhagen IA, Pyza E (1996) Daily rhythms in cells of the fly's optic lobe: taking time out from the circadian clock. Trends Neurosci 19:285-291

Meinertzhagen IA, Pyza E (1999) Neurotransmitter regulation of circadian structural changes in the fly's visual system. Microsc Res Tech 45:96-105

Mertens I, Vandingenen A, Johnson EC, Shafer OT, Li W, Trigg JS, De Loof A, Schoofs L, Taghert PH (2005) PDF receptor signalling in Drosophila contributes to both circadian and geotactic behaviors. Neuron 48:213-219

Mortin LI, Marder E (1991) Differential distribution of beta-pigmentdispersing hormone (beta-PDH)-like immunoreactivity in the stomatogastric nervous system of five species of decapod crustaceans. Cell Tissue Res 265:19-33

Nässel DR, Shiga S, Wikstrand EM, Rao R (1991) Pigment-dispersing hormone-immunoreactive neurons and their relation to serotonergic neurons in the blowfly and cockroach visual system. Cell Tissue Res 266:511-523

Nässel DR, Shiga S, Mohrherr CS, Rao KR (1993) Pigmentdispersing hormone-like peptide in the nervous system of the flies Phormia and Drosophila: immunocytochemistry and partial characterization. J Comp Neurol 331:183-198

Naylor E (1988) Rhythmic behaviour of decapod crustaceans. Symp Zool Soc Lond 59:177-199

Naylor E (1996) Crab clockwork: the case for interactive circatidal and circadian oscillators controlling rhythmic locomotor activity of Carcinus maenas. Chronobiol Int 13:153-161

Nussbaum T, Dircksen H (1995) Neuronal pathways of classical crustacean neurohormones in the central nervous system of the woodlouse, Oniscus asellus (L.). Phil Trans R Soc Lond Biol 347:139-154

Palmer JD (2001) The clocks controlling the tide-associated rhythms of intertidal animals. BioEssays 22:32-37

Park JH, Hall JC (1998) Isolation and chronobiological analysis of a neuropeptide pigment-dispersing factor gene in Drosophila melanogaster. J Biol Rhythms 13:219-228

Persson MGS, Eklund MB, Dircksen H, Muren JR, Nässel DR (2001) Pigment-dispersing factor in the locust abdominal ganglia may have roles as circulating neurohormone and central neuromodulator. J Neurobiol 48:19-41

Petri B, Stengl M (1997) Pigment-dispersing hormones shifts the phase of the circadian pacemaker of the cockroach Leucophaea maderae. J Neurosci 17:4087-4093

Petri B, Stengl M (1999) Presumptive insect circadian pacemakers in vitro: immunocytochemical characterization of cultured pigmentdispersing hormone-immunoreactive neurons of Leucophaea maderae. Cell Tissue Res 296:635-643 
Petri B, Stengl M, Würden S, Homberg U (1995) Immunocytochemical characterization of the accessory medulla in the cockroach Leucophaea maderae. Cell Tissue Res 283:3-19

Powell BL (1966) The control of the 24 hour rhythm of colour change in juvenile Carcinus maenas (L.). Proc R Irish Acad 64:379-399

Pyza E (2001) Cellular circadian rhythms in the fly's visual system. In: Denlinger DL, Giebultowicz JM, Saunders DS (eds) Insect timing: circadian rhythmicity to seasonality. Elsevier, London New York, pp 55-68

Pyza E (2002) Dynamic structural changes of synaptic contacts in the visual system of insects. Microsc Res Tech 58:335-344

Pyza E, Meinertzhagen I (1996) Neurotransmitters regulate rhythmic size changes amongst cells in the fly's optic lobe. J Comp Physiol [A] 178:33-45

Pyza E, Meinertzhagen IA (1997) Neurites of period-expressing PDH cells in the fly's optic lobe exhibit circadian oscillations in morphology. Eur J Neurosc 9:1784-1788

Pyza E, Meinertzhagen IA (1998) Neurotransmitters alter numbers of synapses and organelles in photoreceptor terminals in the lamina of the housefly, Musca domestica. J Comp Physiol [A] 183:719727

Pyza E, Siuta T, Tamimura T (2003) Development of PDFimmunoreactive cells, possible clock neurons, in the housefly Musca domestica. Microsc Res Tech 62:101-113

Rao RK, Riehm JP (1989) The pigment-dispersing hormone family: chemistry, structure-activity relations, and distribution. Biol Bull 177:225-229

Rao KR, Riehm JP (1993) Pigment-dispersing hormones. Ann NY Acad Sci 680:78-88

Rao KR, Riehm JP, Zahnow CA, Kleinholz LH, Tarr GE, Johnson WH, Norton S, Landau M, Semmers OJ, Sattelberg RM, Jorenby WH, Hintz MF (1985) Characterization of a pigment-dispersing hormone in the eyestalks of the fiddler crab Uca pugilator. Proc Natl Acad Sci USA 82:5319-5322

Reischig T, Stengl M (1996) Morphology and pigment-dispersing hormone immunocytochemistry of the accessory medulla, the presumptive circadian pacemaker of the cockroach Leucophaea maderae: a light- and electron-microscopic study. Cell Tissue Res 285:305-319

Reischig T, Stengl M (2002) Optic lobe commissures in a threedimensional brain model of the cockroach Leucophaea maderae: a search for the circadian coupling pathways. J Comp Neurol 443:388-400

Reischig R, Stengl M (2003) Ectopic transplantation of the accessory medulla restores circadian locomotor rhythms in arrhythmic cockroaches (Leucophaea maderae). J Exp Biol 206:1877-1886

Reischig T, Petri B, Stengl M (2004) Pigment-dispersing hormone (PDH)-immunoreactive neurons form a direct coupling pathway between the bilaterally symmetric circadian pacemakers of the cockroach Leucophaea maderae. Cell Tissue Res 318:553-564

Renn SCP, Park JH, Rosbash M, Hall JC, Taghert PH (1999) A pdf neuropeptide gene mutation and ablation of PDF neurons each cause severe abnormalities of behavioral circadian rhythms in Drosophila. Cell 99:791-802

Saunders DS (2002) Insect clocks. Elsevier, Amsterdam
Schachtner J, Schmidt M, Homberg U (2005) Organization and evolutionary trends of primary olfactory centers in Tetraconata (Crustacea + Hexapoda). Arthropod Struct Dev 34:257-299

Sehadová H, Sauman I, Sehnal F (2003) Immunocytochemical distribution of pigment-despersing hormone in the cephalic ganglia of polyneopteran insects. Cell Tissue Res 312:113-125

Stengl M, Homberg U (1994) Pigment-dispersing hormone immunoreactive neurons in the cockroach Leucophaea maderae share properties with circadian pacemaker neurons. J Comp Physiol [A] 175:203-213

Strausfeld NJ (2005) The evolution of crustacean and insect optic lobes and the origin of chiasmata. Arthropod Struct Dev 34:235-256

Strausfeld NJ, Strausfeld C, Stowe S, Rowell D, Loesel R (2006a) Arthropod phylogeny: onychophoran brain organization suggests an archaic relationship with a chelicerate stem lineage. Proc Biol Sci 273:1857-1866

Strausfeld NJ, Strausfeld C, Stowe S, Rowell D, Loesel R (2006b) The organization and evolutioary implications of neuropils and their neurons in the brain of the onychophoran Euperipatoides rowelli. Arthropod Struct Dev 35:169-196

Tomioka K, Saifullah ASM, Koga M (2001) The circadian system of hemimetabolous insects. In: Denlinger DL, Giebultowicz JM, Saunders DS (eds) Insect timing: circadian rhythmicity to seasonality. Elsevier, London New York, pp 43-54

Verde MA, Barriga-Montoya C, Fuentes-Pardo B (2007) Pigment dispersing hormone generates a circadian response to light in the crayfish, Procambarus clarkii. Comp Biochem Physiol [A] 147:983-992

Vilpoux K, Sandeman R, Harzsch S (2006) Early embryonic development of the central nervous system in the Australian crayfish and the Marbled crayfish (Marmorkrebs). Dev Genes Evol 216:209-223

Würden S, Homberg U (1995) Immunocytochemical mapping of serotonin and neuropeptides in the accessory medulla of the locust, Schistocerca gregaria. J Comp Neurol 362:305-319

Zeng C, Naylor E (1996a) Synchronization of endogenous tidal vertical migration rhythms in laboratory-hatched larvae of the crab Carcinus maenas. J Exp Mar Biol Ecol 198:269-288

Zeng C, Naylor E (1996b) Endogenous tidal rhythms of vertical migration in field collected zoea-1 larvae of the shore crab Carcinus maenas: implications for ebb tide offshore displacement. Mar Ecol Prog Ser 132:71-82

Zeng C, Naylor E (1996c) Occurrence in coastal waters and endogenous tidal swimming rhythms of late megalopae of the shore crab Carcinus maenas: implications for onshore recruitment. Mar Ecol Prog Ser 136:69-79

Zeng C, Naylor E (1996d) Heritability of circatidal vertical migration rhythms in zoea larvae of the crab Carcinus maenas (L.). J Exp Mar Biol Ecol 202:239-257

Zeng C, Naylor E (1997) Rhythms of larval release in the shore crab Carcinus maenas (Decapoda, Brachyura). J Mar Biol Assoc UK 77:451-461

Zeng C, Naylor E, Abello P (1997) Endogenous control of timing of metamorphosis in megalopae of the shore crab Carcinus maenas. Mar Biol 128:299-305 